\title{
LYMPH VASCULAR SYSTEM OF THE INTERSTITIAL TISSUE OF THE TESTIS AS REVEALED BY ELECTRON MICROSCOPY
}

\author{
DON W. FAWCETT, PAUL M. HEIDGER AND LEE VIRN LEAK \\ Department of Anatomy and Laboratories for Human Reproduction and Reproductive \\ Biology, Harvard Medical School, Boston, Massachusetts
}

(Received 28th May 1968)

\begin{abstract}
Summary. Testes from guinea-pig and chinchilla were studied with the electron microscope after vascular perfusion of glutaraldehyde or acrolein. The improved preservation achieved by this method of fixation permitted the demonstration of an extensive system of very thin-walled lymphatic sinusoids in the interstitial tissue. The lymphatic endothelium is closely applied to the lamina propria of the seminiferous tubules on the one side and to the clusters of interstitial cells on the other. It is suggested that these lymphatics may have an important function in the distribution of androgens within the testis, in addition to their role in returning to the general circulation the large amount of serum protein that escapes from the highly permeable blood capillaries of the interstitium.
\end{abstract}

\section{INTRODUCTION}

The literature on the lymphatics of the testis is highly contradictory. It is generally agreed that there is a rich plexus of subserosal lymph vessels in the tunica albuginea and that, in large mammals, these extend into the septula testis. There is no unanimity, however, as to the existence of lymphatic vessels in the interstitial tissue. Ludwig \& Tomsa (1862) described a system of intertubular connective tissue clefts which were presumed to be in open communication with typical lymphatics in the septula. Their concept of interstitial connective tissue spaces which served as sites of accumulation of lymph and as channels for its drainage into open lymphatics appears to have been shared by Frey (1863), Regaud (1897) and Testut (1902). However, Mikálkovics (1873) reported successful injection of interstitial lymphatics in the human testis and Gerster (1876) demonstrated an extensive system of lymphatic capillaries in the interstitial tissue of the bull and ram testis. An extraordinarily rich lymphatic network in the interstitium of the rabbit testis was reported by Hasumi (1930).

More recent investigators, on the other hand, have tended to discount earlier reports based upon injection of the lymphatics, on the basis that they are subject to serious artifact, and have preferred instead to ligate the efferent lymphatics, and to fix and stain the lymph impounded in the system distal to the ligature. Using this method, Rényi-Vámos $(1955,1956)$ found lymphatics only outside of the parenchyma in dog and human testis. Von Brzezinski (1963) 
working with the guinea-pig-one of the species used in the present study-found lymphatics only in the organ capsule and concluded that all of the better evidence speaks against the existence of lymphatic capillaries in the interior of the testis. More recently, Staudt \& Wenzel (1965), working with the rabbit, found lymphatics in the septula, rete testis and tunica albuginea but not in the interstitial tissue.

On the contrary, the present paper describes an extensive system of lymphatic vessels in the interstitium of the guinea-pig and chinchilla testis. Although there have been a number of earlier electron microscopic studies of the interstitium of the testis (Fawcett \& Burgos, 1961; Christensen, 1965; Christensen \& Fawcett, 1966) none has contributed to a solution of this problem. The very thin walls of the lymphatics have little connective tissue support. Thus the rotational and shearing forces that are brought to bear upon the seminiferous tubules in the process of excising small pieces of fresh testicular tissue, generally distort and disrupt the tenuous walls of the interstitial lymphatics. The greater success of the present effort is attributed to perfusion of acrolein or glutaraldehyde which fixes the tissue components in situ and hardens the organ sufficiently to permit cutting of small blocks with minimal internal distortion.

The relation of the interstitial lymphatics to the blood vascular system and the Leydig cells is discussed with respect to the high rate of extravascular accumulation of protein in the testis (Mancini, Vilar, Alvarez \& Seigner, 1965) and the partition of androgenic steroids between the lymph and venous blood (Lindner, 1963).

\section{MATERIALS AND METHODS}

The observations are based upon examination of five large male guinea-pigs and two chinchillas. The perfusion procedure was an adaptation of the method described by Christensen (1965). Physiological salt solution in a reservoir at a height of $130 \mathrm{~cm}$ ran through No. PE 60 polyethylene tubing to the shaft of a 26-gauge needle removed from the hub and with the tip slightly blunted on a hone. Under deep ether anaesthesia, the testis was delivered through a scrotal incision and a silk suture placed under the spermatic artery at the upper pole of the testis. The needle was introduced into the vessel and tied in with the suture. The testis immediately blanched as the saline displaced the blood. As soon thereafter as practicable, the saline was drained from the reservoir through a side tube and replaced with the fixative, and the testis was removed from the animal by cutting the spermatic cord and the site of adhesion of the lower pole of the testis to the floor of the sac formed by the processus vaginalis and the cremaster muscle.

Three fixatives were used with satisfactory results: (1) $5 \%$ acrolein purified according to the method of Aldridge (personal communication) and made up in tissue culture medium 199, (2) s-collidine buffered $5 \%$ glutaraldehyde and (3) a mixture of picric acid, paraformaldehyde and glutaraldehyde based upon the formula described by Stefanini, DeMartino \& Zamboni (1967).

The perfusion was continued for 30 to $45 \mathrm{~min}$. The hardened testis was then cut into small cubes with a sharp razor and immersed in fixative for an addi- 
tional $30 \mathrm{~min}$. After repeated rinsing in the buffer, the tissues were fixed in collidine- or phosphate-buffered $1 \%$ osmium tetroxide for $1 \mathrm{hr}$ and then rapidly dehydrated through $50,80,95 \%$ and absolute alcohols. Embedding was in Epon. One-half and one micron sections were stained with toluidine blue in borax (Richardson, Jarrett \& Finke, 1960) for light microscopy and thin sections exhibiting pale yellow to silver interference colours were cut with diamond knives on a Sorvall MT-1 microtome. The sections were stained with aqueous uranyl acetate and lead citrate (Venable \& Coggeshall, 1965) and examined in RCA-EMU-3G or Phillips 200 electron microscopes.

\section{Histological observations}

\section{RESULTS}

Examination of Epon sections of perfused testis with the light microscope reveals certain aspects of the organization of the interstitial tissue that escape detection in the thicker paraffin sections upon which most of the classical studies of this organ have relied. The quality of the preservation is generally excellent and uniform throughout the block (Pl. 1, Figs. 1 and 2). There is no evidence that any interstitial oedema has resulted from the perfusion. Indeed, the interstices between the seminiferous tubules are generally smaller than in preparations of testis that have been fixed by immersion. The blood vessels are open and devoid of contents. Leydig cells in clusters of varying size are closely related to the vessel walls but in the guinea-pig and chinchilla comprise only a small fraction of the interstitial tissue. The remainder of the intertubular space is relatively acellular and free of microscopically visible collagenous or elastic fibres. These areas are occupied instead by a homogeneous substance of low density and smooth texture reminiscent of well-fixed blood plasma or connective tissue ground substance (Pl. 1, Fig. 2). Gloser inspection discloses exceedingly thin linear densities surrounding the groups of Leydig cells and traversing the open areas of homogeneous substance (see at arrows in Pl. 1, Fig. 2). The occasional association of slender, elongated nuclei with these linear structures suggests that they are sections of an extremely thin lymphatic endothelium and this is borne out by the results of electron microscopy to be described below. The spaces bounded by this endothelium are so variable in calibre and irregular in shape that they would be more accurately described as sinusoids than as typical lymphatic capillaries.

Another feature of interest observed in such preparations is the appearance of the tunica propria of the seminiferous tubules. A single continuous layer of flattened cells surrounds the seminiferous tubules and marks the outer limit of the tunica propria. Though epithelial in shape and in mode of association, these cells have been shown to resemble smooth muscle cells and are believed by some workers to be contractile (Clermont, 1958; Ross, 1967). This cellular layer is separated from the basement lamina of the epithelium by a narrow clear zone of rather uniform width (Pl.1, Fig.2). The content of this 'intermediate zone of the tunica propria' is of considerably lower density than that of the intertubular spaces which suggests that the homogeneous material of low density that permeates the interstitium is excluded from this compartment of the tunica propria. 


\section{Electron microscopic observations}

The tunica propria of the seminiferous tubules was described by Regaud (1897) as composed of two concentric lamellae of a homogeneous substance enclosing a continuous layer of flattened cells. Although in cross sections of the tubules, these cells had the fusiform shape of fibroblasts, he was able to demonstrate in tangential sections of tubules stained with silver nitrate that these cells are, in fact, polygonal when they are viewed on the flat and they meet edge-to-edge like the cells of a squamous epithelium. He regarded them as a specialized form of connective tissue cell. However, when studied with the electron microscope half a century later, these cells were found to possess several of the cytological characteristics of smooth muscle cells including numerous superficial vesicles and ordered arrays of cytoplasmic filaments. Clermont (1958) therefore suggested that they were probably responsible for the periodic contractions which he observed in isolated seminiferous tubules. Roosen-Runge (1959) also described peristaltic movements of the tubules but attributed these to contractility of the Sertoli cells. The view that it is the cells of the tunica propria that are contractile has recently been strongly supported by Ross (1967).

The layer of myoid cells is coated on its inner and outer surfaces by a layer of protein-polysaccharide corresponding to that which invests the sarcolemma of muscle or to that comprising the basement lamina of epithelia. This led Clermont to refer to the contractile elements as 'interlaminar cells', but Ross favours the term 'peritubular contractile cells'. That these cells have contractile properties is now widely accepted. There is as yet no consensus of opinion as to whether they should be regarded as a special form of contractile epithelium (Clermont, 1958) or as modified smooth muscle cells with an epithelioid pattern of association (Lacy \& Rotblat, 1960; Ross, 1967). There seems to be general agreement, however, upon their cytological resemblance to smooth muscle cells at the electron microscope level. Hence, 'myoid layer of the tunica propria' may be the most generally acceptable term.

This cellular layer is about 0.5 to $1 \mu$ thick and is separated from the basement lamina of the seminiferous epithelium by a clear zone, 1 to $2 \mu$ wide. This contains a moderate number of unit fibrils of collagen which vary in their orientation but tend to run parallel to the long axis of the tubule. They are seldom associated in coherent bundles that would be visible as discrete reticular or collagenous fibres with the light microscope. No ground substance is preserved in this subepithelial clear zone and, apart from its sparse content of collagen fibrils, it appears quite empty in electron micrographs (Pl. 2, Fig. 3). It seems likely that the contents of this zone are more fluid than the matrix of most connective tissues.

As a rule the peritubular contractile cells form a single layer, but in some tubules there is a more-or-less complete second layer of cells of identical cytological characteristics. When such a second layer is present, it is coated on both sides by a 500 to $600 \AA$ protein-polysaccharide boundary layer and is separated from the first by an interspace about $0.5 \mu$ wide containing a small amount of collagen. It is more common to find a single layer of contractile cells closely invested on its outer aspect by a layer of extremely attenuated cells only 
700 to $1000 \AA$ thick, except where their cytoplasm is thickened to accommodate a flattened nucleus (Pl. 2, Fig. 3, and Pl. 4, Fig. 5). Unlike the myoid layer of the tunica propria, this layer of squamous cells lacks a protein-polysaccharide basement lamina or boundary layer and is interpreted as lymphatic endothelium. A similar layer often surrounds blood vessels and their associated interstitial cells (Pl. 3, Fig. 4, and Pl. 5, Fig. 6). This tenuous endothelium appears to delimit an extensive system of lymphatic channels interposed between the seminiferous tubules and the perivascular cords and islands of Leydig cells.

Earlier electron microscopic studies of the lymphatics in the small intestine (Palay \& Karlin, 1959), the diaphragm (French, Florey \& Morris, 1960; Casley-Smith \& Florey, 1961) and the glabrous skin of the rat penis (Fraley \& Weiss, 1961) describe these vessels as extremely irregular in shape and lacking a continuous basement lamina. In more recent studies of lymphatic vessels in the dermis of guinea-pigs and mice, Leak \& Burke $(1966,1968)$ defined several ultrastructural characteristics which serve to differentiate these vessels from blood capillaries. The lymphatics possess: (1) a wider and more irregular lumen than the blood capillary, (2) endothelium with an extremely attenuated cytoplasm except in the nuclear region, (3) a discontinuous basement lamina, (4) endothelial cell junctions generally lacking the so-called tight junctions that have been described for some blood capillaries, and (5) anchoring filaments which terminate on the vessel wall and serve to connect the vessel wall to the adjoining connective tissue. These filaments may play a role in maintaining the patency of its lumen. The vessels described here for the testis conform in most respects to this description of lymphatics in other tissues. Though occasional small bundles of collagen fibres occupy recesses in the base of the endothelium, typical anchoring filaments of the kind described by Leak \& Burke were seldom seen, but this may well be related to the fact that the fibrous components of the interstitial connective tissue in general, were very sparse. The endothelial-lined spaces described here undoubtedly constitute the primary or initial elements of a lymphatic system that drains the parenchyma of the testis and plays an important role in the fluid homeostasis of this organ. Although lymphatic capillaries in general are far more variable in calibre than blood capillaries, those of the interstitium of the testis are so pleomorphic and labyrinthine in their three-dimensional configuration that they are probably more accurately described as 'lymphatic sinusoids' than as capillaries. Their lumen is filled by a fine flocculent precipitate interpreted to be a product of coagulation of protein-rich lymph by the fixative.

The perivascular areas of interstitial tissue bounded on the outside by lymphatic endothelium are composed of an exceedingly loose connective tissue that surrounds the blood vessels and extends into the interstices among the Leydig cells. Small bundles of collagen fibrils are present but are few and scattered. Spindle-shaped cells presumed to be fibroblasts and rare macrophages and mononuclear leucocytes are encountered, but the population of connective tissue cells is surprisingly sparse. The amorphous extracellular phase of this loose connective tissue is a fine flocculent precipitate which is identical in appearance, and presumably in composition, to that filling the lumen of the lymphatics (Pl. 4, Fig. 5). 
The absence of a significant difference in the concentration of this protein material in the interstitial connective tissue and in the lymph vascular system may be attributable to the presence of discontinuities in the lymphatic endothelium. An example can be seen in Pl. 4, Fig. 5, and Pl. 6, Fig. 7. Such images inevitably raise the question as to whether they existed in life or were produced in specimen preparation. The fact that, in this study employing perfusion, there was no cutting or other potentially disruptive manipulation of the tissue before fixation, lends credence to our suggestion that these openings are real. In our experience with other methods of preparation where breaks in endothelia are artifacts one observes free edges of the endothelial plasma membranes on either side of the hiatus. Such is not the case here. The membranes of the luminal and abluminal surfaces are continuous over the ends of the endothelial cell profiles on both sides of the opening. Furthermore, when endothelial continuity has been broken by trauma before fixation, there is usually electron microscopic evidence of it in the form of a local decrease in intraluminal density or other signs of out-welling of the contents of the vessel. In the material studied here, there was no local discontinuity of density from the inside to the outside of the vessel in the region of the opening. We conclude therefore that the intertubular lymphatic sinusoids of the guinea-pig testis are not completely closed but that their Iumen is occasionally in direct communication with the extravascular spaces of the interstitium through small, naturally occurring, discontinuities in the endothelium.

In view of the morphological evidence presented here and the physiological evidence for a high rate of extravascular accumulation of protein in the testis (Everett \& Simmons, 1958; Mancini et al., 1965), it was of interest to examine the fine structure of the interstitial blood capillaries and venules. These are invariably of the type having a continuous endothelial wall of appreciable thickness. Although high resolution micrographs of the endothelial cell junctions were not made, there was nothing in their appearance at low and intermediate magnifications to suggest that they differ from those of capillaries in muscle. The finding of this type of blood capillary in the interstitium of the testis was unexpected since in other endocrine glands including the pituitary, adrenal, thyroid, parathyroid and the pancreas, capillaries are of the fenestrated type. It was anticipated that the endocrine portion of the testis would conform to the same pattern. Since fenestrated capillaries occur also at sites of rapid filtration or absorption such as the glomerulus and the intestinal mucosa, vessels of this structure would seem to be more in keeping with the high flux of fluid and protein known to take place across the capillary wall in the testis. No explanation has been offered for the paradoxical occurrence of muscle-type capillaries in this endocrine gland.

\section{DISCUSSION}

The present investigation has brought the higher resolution of the electron microscope to bear upon the old controversy as to whether or not the lymphatics of the testis extend into the interstitial tissue. The micrographs obtained after fixation by perfusion seem to us to establish that in the guinea-pig and chinchilla, 
there is an extensive system of sinusoidal lymphatics in intimate relation both with the Leydig cells and the tunica propria of the seminiferous tubules. Although the walls of the lymphatics are for the most part continuous, occasional gaps observed in electron micrographs between the edges of endothelial cells are believed to represent true openings that exist in life. Certain of the early investigators, unable to resolve the exceedingly thin endothelium with the light microscope seem to have interpreted some of the larger lymphatic sinusoids as connective tissue clefts that accumulated fluid and drained it into open lymphatics in the septula or in the capsule (Ludwig \& Tomsa, 1862). Re-examination of the illustrations in published electron microscopic studies of this organ suggests that when the testis is cut up into small blocks before fixation by immersion, lymph escapes, lymphatics collapse and the continuity of their delicate walls is extensively disrupted. As a consequence of these alterations, the interstitial tissue in such preparations appears more cellular and endothelial cells are easily mistaken for slender fibroblasts.

Of special interest is the fact that the methods of fixation used in the present study preserved the protein of the tissue fluid and lymph, and provided morphological evidence substantiating earlier experimental studies that have reported an unusually high permeability of interstitial capillaries to serum proteins. Mancini et al. (1965), studying the extravascular diffusion of fluorescein-labelled serum protein in the rat testis, demonstrated a rapid passage of intact protein through the vessel walls. In earlier quantitative studies in the same species using iodinated albumen, Everett \& Simmons (1958) found that of all the organs studied, the greatest increase in extravascular content of albumen was in the testis, amounting to $167 \%$ increase at $30 \mathrm{~min}$ and $316 \%$ at $1 \mathrm{hr}$. It was noted that the organs which showed a marked increase in labelled albumen content with time after injection are all characterized by having a loose areolar connective tissue or 'structureless matrix' like that in the intertubular spaces of the testis, and autoradiographs showed that the extravascular albumen accumulated in those areas. They interpreted these findings as evidence that, in addition to the character of the capillary walls, the nature and amount of extracellular connective tissue was also an important determinant of the rate of passage of protein into the extracellular tissue compartment. The present observations tend to support this view by demonstrating that the connective tissue in the interstitium of the guinea-pig testis is unusually loose in its organization and is filled with protein-rich extracellular fluid, despite the fact that the blood capillaries are not of the type which would be expected to be unusually permeable to large molecules. Although the abundance of the endocrine cells and the character and organization of the interstitial connective tissue vary greatly from species to species, there is evidence for a high permeability of the interstitial vessels to serum protein in large domestic animals as well as in the small laboratory rodents. In the anaesthetized ram, Lindner (1963) was able to collect lymph at a mean rate of $7.5 \mathrm{ml} / \mathrm{hr} /$ testis and upon electrophoresis found that its protein composition was similar to that of plasma. Only the concentration of the slow $\alpha$ globulin was appreciably lower in the lymph samples.

The seminiferous tubules have a cross-sectional area that would include over 100 capillaries in muscle (Bascom \& Osterud, 1927). It is surprising that the 
thick germinal epithelium wherein cells are continually proliferating and carrying out complex synthetic and morphogenetic activities essential to the propagation of the species, is so avascular. Essential metabolites must diffuse over distances of up to $120 \mu$ to reach germ cells near the lumen of the tubule and there has been much speculation as to the possible role of the Sertoli cell in facilitating exchange between the blood and the germ cells (Vilar, Pérez Del Cerro \& Mancini, 1962). It is now known that there is a substantial movement of fluid across the germinal epithelium and the accumulation of this fluid in the lumen of the tubules and its flow toward the rete testis and ductuli efferentes is considered to play a major role in transport of the spermatozoa to the epididymis. In the ram where it has been possible to collect the outflow from the cut ends of the ductuli efferentes in the conscious, unrestrained animal, the testicular fluid has been shown to flow at a rate of $1 \mathrm{ml} / \mathrm{hr} / 100 \mathrm{~g}$ of testis or about $100 \mathrm{ml} /$ day from both testes (Voglmayer, Waites \& Setchell, 1966). In marked contrast to the high protein concentration of testicular lymph in this species (Lindner, 1963; Lindner, Sass \& Morris, 1964), the cell-free testicular fluid contains very little protein $(0.1$ to $0.5 \mathrm{~g} / 100 \mathrm{ml})$. Thus the serum proteins of the interstitial fluid appear to be largely excluded from the seminiferous tubules. The electron microscopic observations presented here suggest that the principal barrier to their entry into the germinal epithelium is the continuous sheet of peritubular contractile cells, because the protein precipitate that extends throughout the interstitium external to this layer, is notably absent from the zone of loose connective tissue between this layer and the base of the seminiferous epithelium.

It is evident that the formation of testicular fluid is not entirely a passive filtration, but also involves active secretion since fluid continues to accumulate under pressure after ligation of the efferent ducts and leads to dilatation and atrophy of the epithelium (Smith, 1962). Furthermore, Setchell (1967) has shown that the chloride content of the fluid is $20 \%$ higher and the glutamic acid concentration ten times greater than in spermatic vein plasma. Nevertheless, the high rate of movement of fluid into the extravascular compartment of the interstitial tissue is probably necessary to maintain the production of testicular fluid, and a well-developed system of lymphatics may be required to return to the circulation the serum proteins which are very largely excluded from the seminiferous tubules.

In considering the histo-physiology of the endocrine glands, great emphasis has been placed upon the importance of a close topographical relation between the parenchymal cells and the capillaries. But of late, there has been renewed interest in the possible role of the lymphatics in the delivery of hormones to the circulation (Daniel, Excell, Gale \& Pratt, 1962; Lindner, 1963; Lindner et al., 1964). Some of the classical investigations of the histology of the testis described the Leydig cells as forming sheaths around the intertubular capillaries. Others were unable to verify such an arrangement and some workers have questioned whether there is any specific relationship between the Leydig cells and the blood vessels. In the guinea-pig and chinchilla studied here, the Leydig cells are clearly in proximity to blood vessels, but they are no more consistently or intimately associated with capillaries than they are with arterioles and small 
veins whose walls would seem too thick to permit ready diffusion of androgens into the blood. A great many of the capillaries and small venules encountered in sections of interstitial tissue have no associated Leydig cells. On the other hand, groups of these cells, whether associated with blood capillaries or larger vessels are nearly always closely invested by the endothelium of a lymphatic sinusoid. Given the thin, and sometimes incomplete, wall of the lymphatic and the fact that protein, which might be required as a carrier of androgen, is nearly as abundant in the connective tissue and lymph as in the blood plasma, it would be surprising if testosterone were not present in lymph in as high or higher concentration than in venous blood. No data are available on the partition of androgens between the blood and the lymph in rodents, but in the ram, Lindner (1963) found levels of testosterone from 2.5 to $10.6 \mu \mathrm{g} / 100 \mathrm{ml}$ in testicular lymph rising to 8.9 to $61.4 \mu \mathrm{g} / 100 \mathrm{ml}$ in animals treated with human chorionic gonadotrophin. These values were approximately two-thirds those of the venous blood but two to eight times higher than arterial blood. Despite the appreciable concentrations in the lymph, it was concluded that only a small fraction of the androgen output of the testis is carried to the general circulation by the lymph, owing mainly to the great difference in rates of flow; blood flow being 300 to 400 times higher than the rate of lymph flow. The respective relations of the Leydig cells to the capillaries and lymphatics in the guinea-pig testis make it difficult to understand how the concentration of androgens in venous blood could exceed that in the lymphatics. It may well be that in the rodents the lymphatics are quantitatively a more important path of egress of androgen from the testis than they are in the ram, but the small size of the animal makes it impossible to collect lymph in sufficient amounts to obtain comparable analytical data.

Generalization to other animals from the observations recorded here for the guinea-pig should be avoided, for there are extraordinary differences from species to species in the abundance of the interstitial endocrine cells, ranging from $1.7 \%$ by volume in the rat (Roosen-Runge, 1955) to $34.7 \%$ in the boar (Bascom \& Osterud, 1927) and probably a considerably higher percentage in the warthog. There may be equally remarkable differences in the organization of the blood and lymph vascular system. In those species with abundant Leydig cells, the interstitial tissue appears very compact and cellular in contrast to the loose organization of the connective tissue and sparse cell population that characterize the testes of the common laboratory rodents.

Studies are now in progress using peroxidase and particulate markers to trace pathways of movements of materials reaching the testis through the bloodstream or injected interstitially.

\section{ACKNOWLEDGMENTS}

Supported in part by grants GM-06729 and HD-02344 from the National Institutes of Health, United States Public Health Service.

\section{REFERENCES}

Bascom, K. F. \& Osterud, H. L. (1927) Quantitative studies of the testis. III. A numerical treatment of the development of the pig testis. Anat. Rec. 37, 63 . 
Casley-Smith, J. R. \& Florey, H. W. (1961) The structure of normal small lymphatics. Q. $\mathcal{F l}$ exp. Physiol. 46, 101.

Christensen, A. K. (1965) The fine structure of testicular interstitial cells in guinea pigs. F. Cell Biol. 26, 911 .

Christensen, A. K. \& Fawcett, D. W. (1966) The fine structure of the interstitial cells of the mouse testis. Am. F. Anat. 118, 551 .

Clermont, Y. (1958) Contractile elements in the limiting membranes of the seminiferous tubules of the rat. Expl Cell Res. 15, 438.

Daniel, P. M., Excell, B.J., Gale, M. M. \& Pratt, O. E. (1962) The drainage of thyroid hormone by the lymphatics of the thyroid gland. F. Physiol., Lond. 160, $6 \mathbf{P}$.

Everett, N. B. \& Simmons, B. (1958) Measurement and radioautographic localization of albumin in rat tissues after intravenous administration. Circulation Res. 6/3, 307.

FawcetT, D. W. \& Burgos, M. H. (1961) Studies on the fine structure of the mammalian testis. II. The human interstitial cells. Am. F. Anat. 107, 245.

FraLEY, E. E. \& WeIss, L. (1961) An electron microscopic study of the lymphatic vessels in the penile skin of the rat. Am. F. Anat. 109, 55.

French, J. E., FloReY, H. W. \& MoRRIS, B. (1960) The absorption of particles by the lymphatic of the diaphragm. Q. $\mathcal{F l}$ exp. Physiol. 45, 88.

FrEY, H. (1863) Zur Kenntniss der lymphatischen Bahnen im Hoden. Virchows Arch. path. Anat. Physiol. 28,563 .

Gerster, R. (1876) Über die Lymphgefässe des Hodens. Z. Anat. EntwGesch. 2, 36.

HASUMI, S. (1930) Anatomische Untersuchungen über die Lymphgefässe des männlichen Urogenitalsystems. Jap. F. med. Sci. Anat. II, 159.

LACY, D. \& Rotblat, J. (1960) Study of normal and irradiated boundary tissue of the seminiferous tubules of the rat. Expl Cell Res. 21, 49.

LEAK, L. V. \& BURKE, J. F. (1966) Fine structure of the lymphatic capillary and the adjoining connective tissue area. Am. F. Anat. 118, 785.

LEAK, L. V. \& BURKE, J. F. (1968) Ultrastructural studies on the lymphatic anchoring filaments. $\mathcal{F}$. Cell Biol. 36, 129.

LiNDNER, H. R. (1963) Partition of androgen between lymph and venous blood of the testis in the ram. 7. Endocr. 25, 483.

Lindner, H. R., SAss, M. B. \& Morris, B. (1964) Steroids in the ovarian lymph and blood of conscious ewes. F. Endocr. 30, 361 .

Ludwig, C. \& Tomsa, W. (1862) Die Lymphwege des Hodens und ihr Verhältnis zu den Blut-und Samengefässen. S. Ber. Akad. Wiss. Wien. Math.-naturw. Kl. Abt. II, 46, 221. (Cited by Staudt \& Wenzel, 1965)

Mancinr, R. E., Vilar, O., Alvarez, B. \& Seigner, A. G. (1965) Extravascular and intratubular diffusion of labelled serum proteins in the rat testis. F. Histochem. Cytochem. 13, 376.

Mikálkovics, V. (1873) Beiträge zur Anatomie und Histologie des Hodens. (Cited by Rényi-Vámos, 1960).

Palay, S. L. \& Karlin, L. J. (1959) An electron microscopic study of the intestinal villus. I. The fasting animal. F. biophys. biochem. Cytol. 5, 363 .

Regaud, CL. (1897) Les vaisseaux lymphatiques de testicule. C. r. Séanc Soc. Biol. 14, 695.

RÉNYI-VÁmos, F. (1955) Das Lymphsystem des Hodens und Nebenhodens. Z. Urol. 48, 353.

RÉNYI-VÁmos, F. (1956) Neue Beiträge und Richtlinien zur Anatomie des Lymphgefässystems. Virchows Arch. path. Anat. Physiol. 328, 503.

RÉnYI-VÁmos, F. (1960) Das innere Lymphgefäss-system der Organe. Anatomie, Pathologie und Klinik. Verlag. Ungar Akad. d. Wissenschaften, Budapest.

Richaroson, K. C., Jarrett, L. \& Finke, E. H. (1960) Embedding in epoxy resins for ultrathin sectioning in electron microscopy. Stain Technol. 35, 313.

Roosen-Runge, E. C. (1955) Quantitative studies on spermatogenesis in the albino rat. III. Volume changes in the cells of the seminiferous tubules. Anat. Rec. 123, 385.

Roosen-RUnge, E. C. (1959) Motions of the seminiferous tubules of rat and dog. (Abstract). Anat. Rec. 109,413 .

Ross, M. H. (1967) The fine structure and development of the peritubular contractile cell component in the seminiferous tubules of the mouse. Am. F. Anat. 121, 523.

Setchell, B. P. (1967) Fluid secretion by the testis. 7. Reprod. Fert. 14, 347.

Sмiтн, G. (1962) Effects of ligation of the vasa efferentia and vasectomy on testicular function in the adult rat. F. Endocr. 23, 385.

Staudt, J. \& Wenzed, J. (1965) Untersuchungen über das Lymphgefässystem des Kaninchenhodens. Z. mikrosk.-anat. Forsch. 73, 60.

Stefanini, M. DeMartino, G. \& Zamboni, L. (1967) Fixation of ejaculated spermatozoa for electron microscopy. Nature, Lond. 216, 173. 
PLITE:

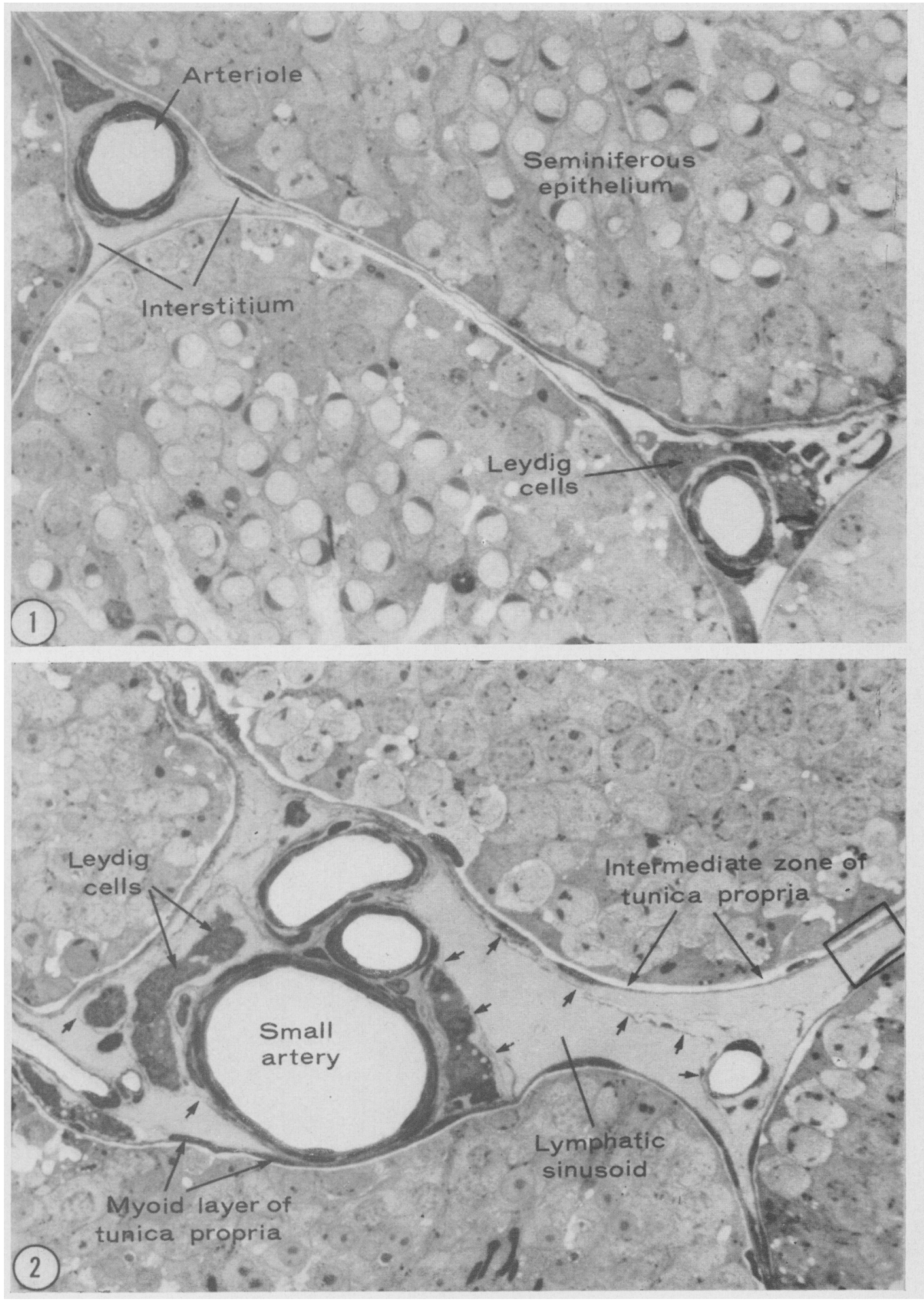

(Firing /. 118) 
PL. ITE:

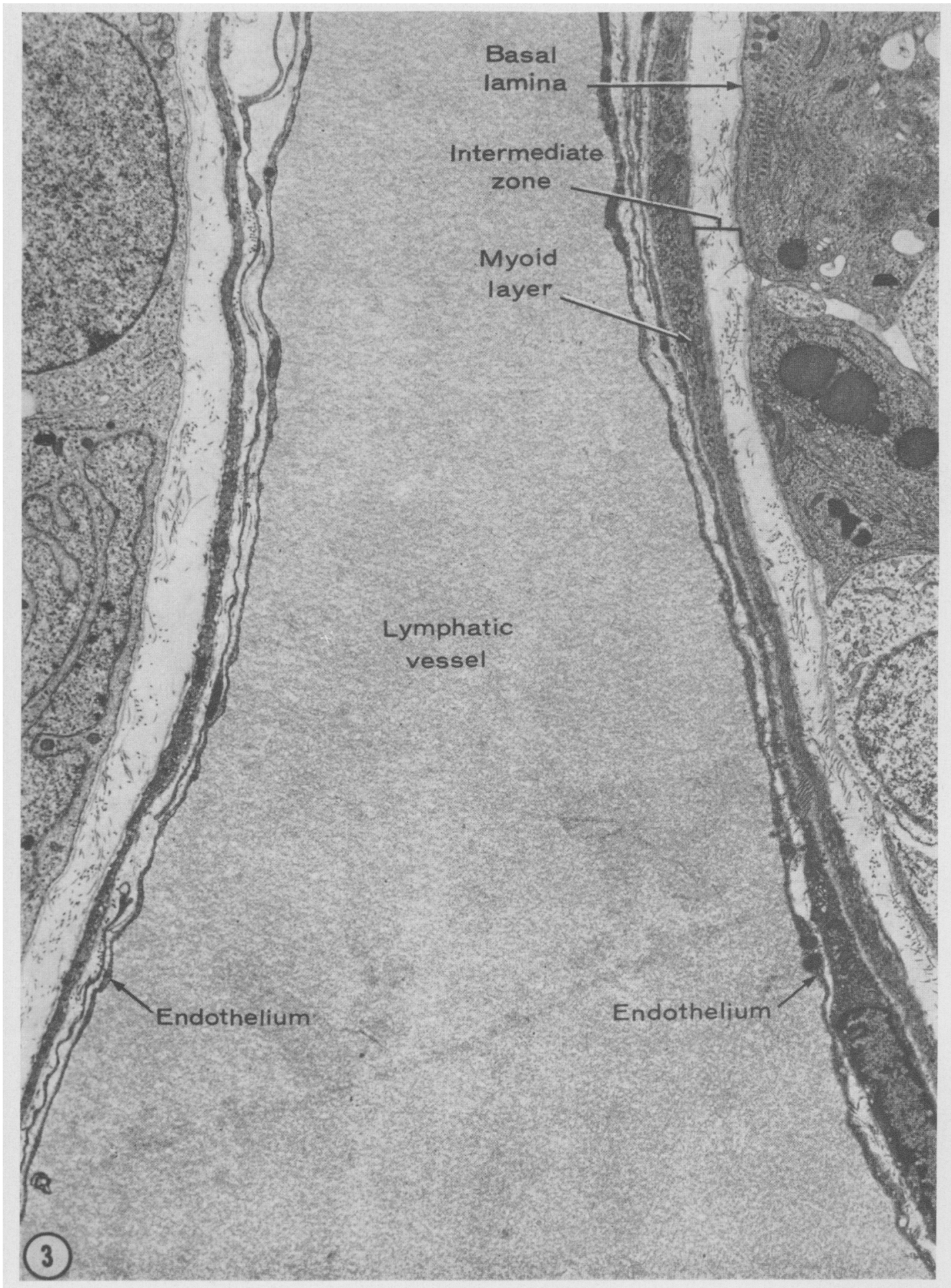


PI.AII: 3

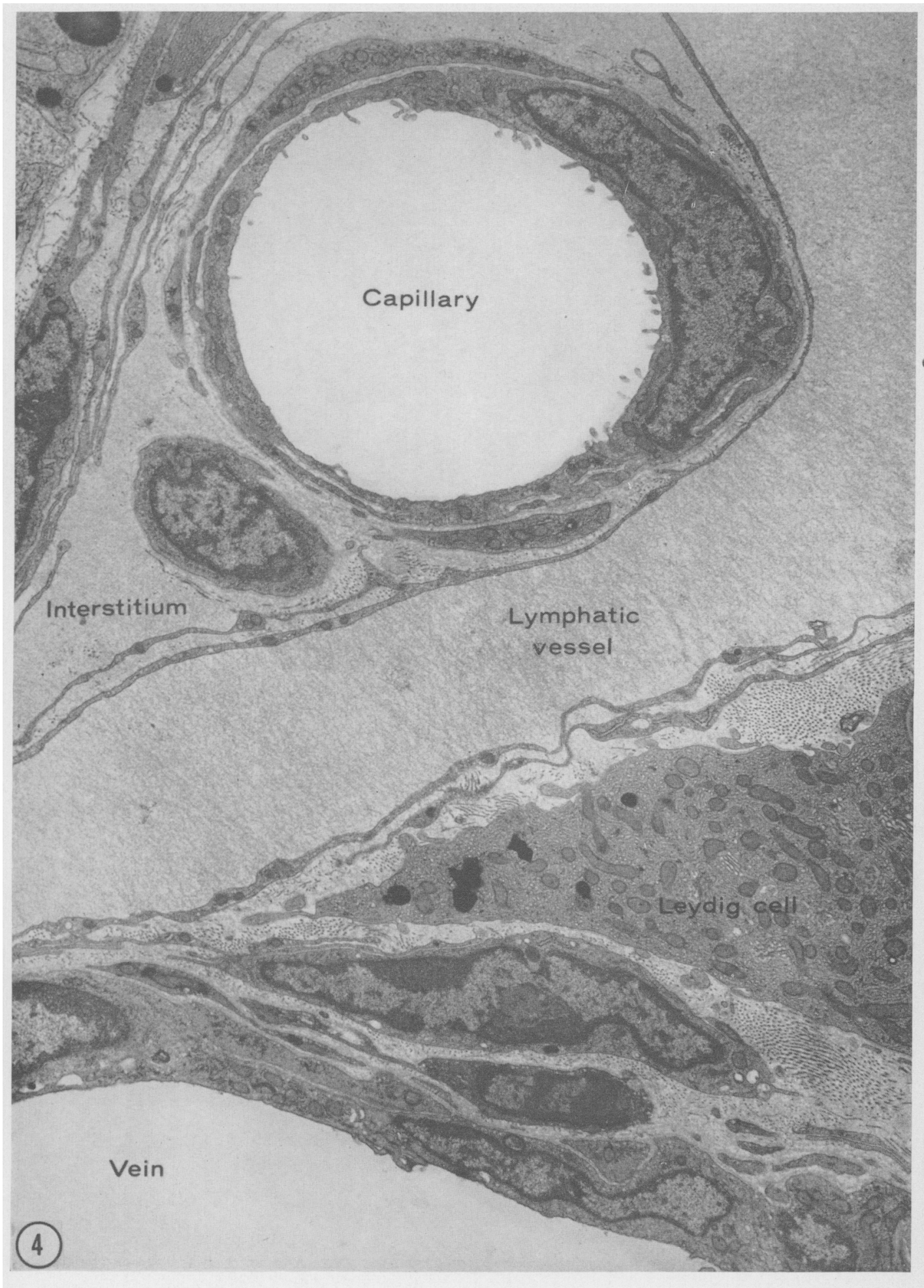


PIATE +

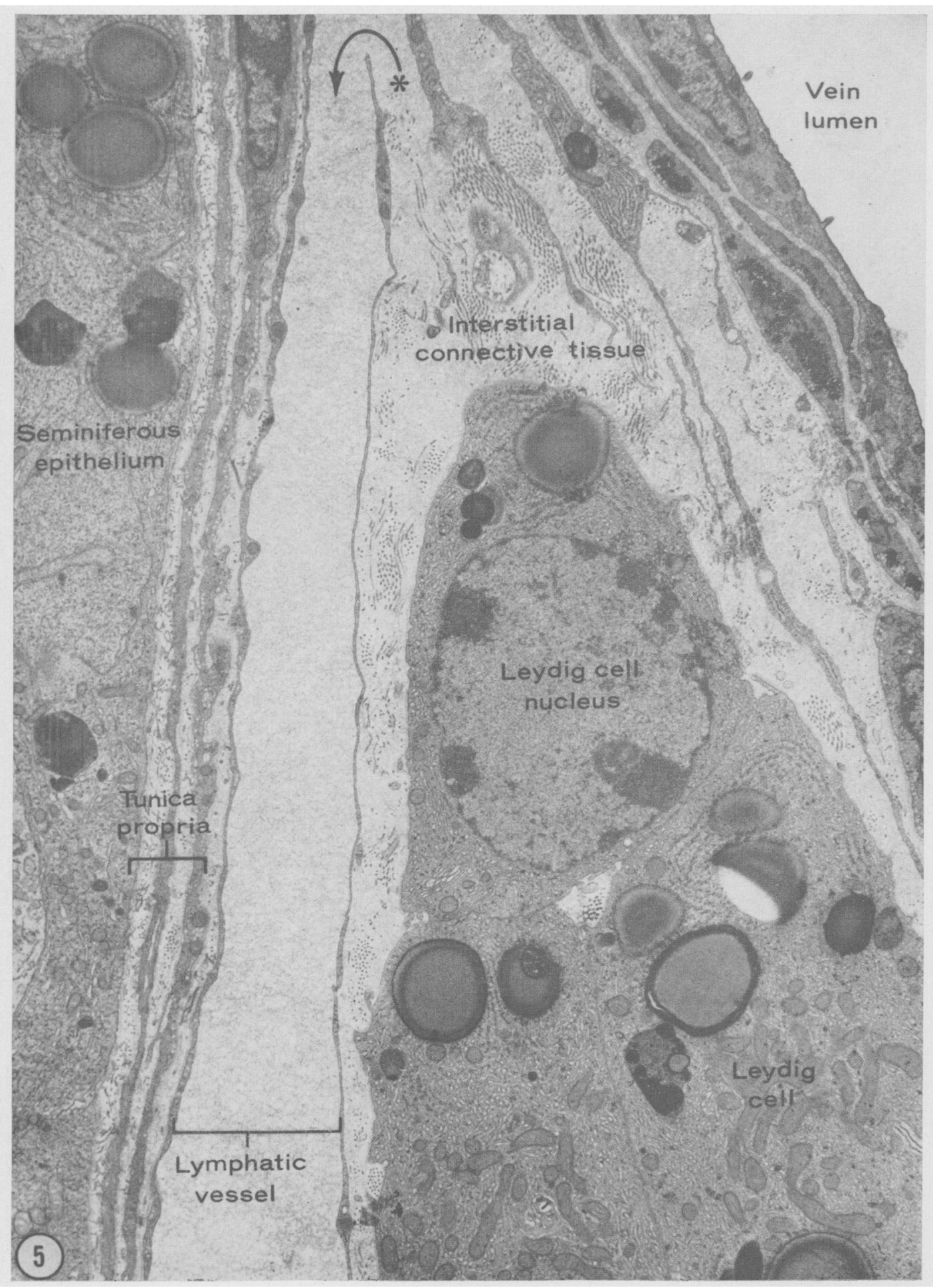


PI.ATE 5

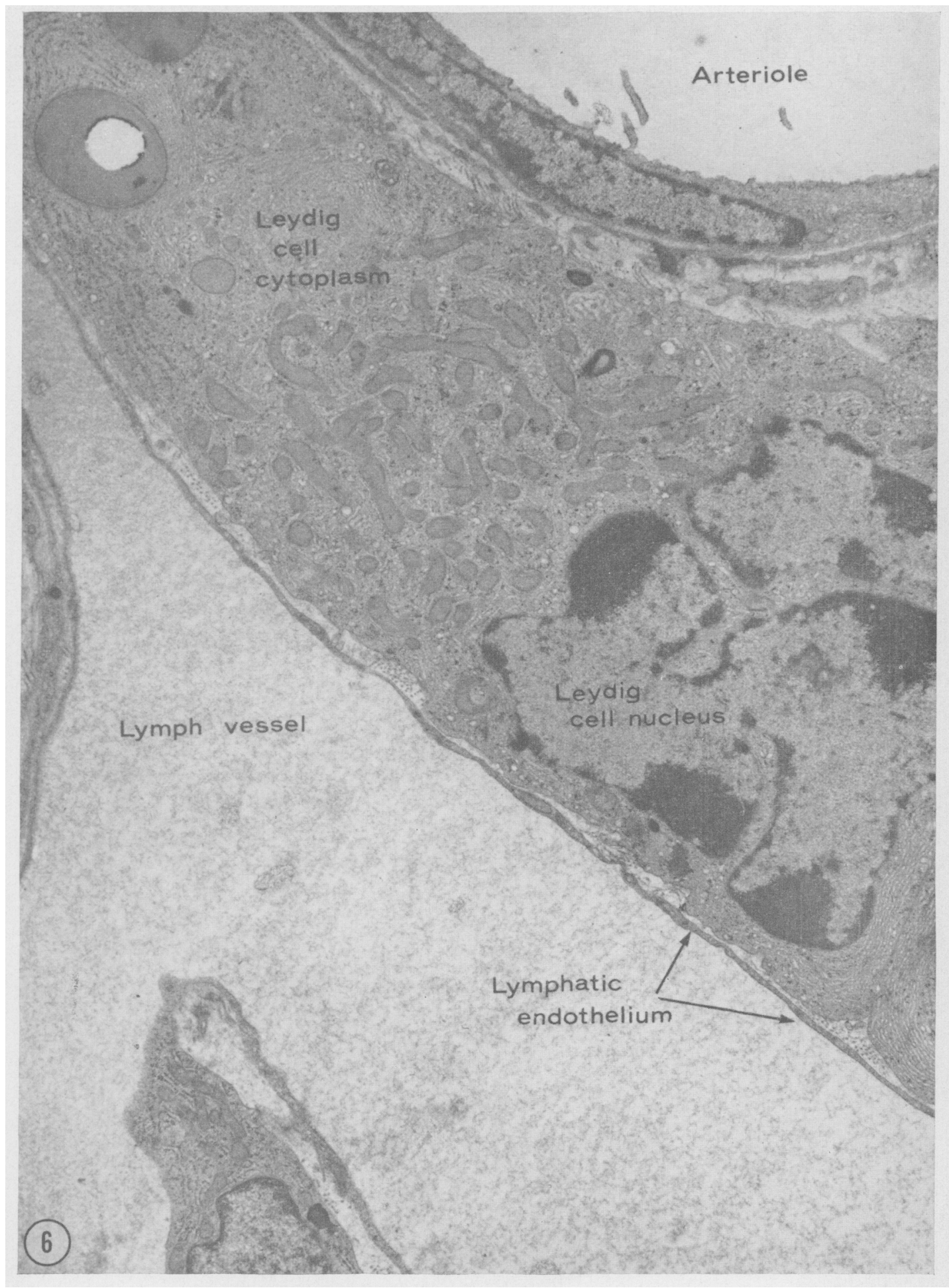


PI. ITI: B

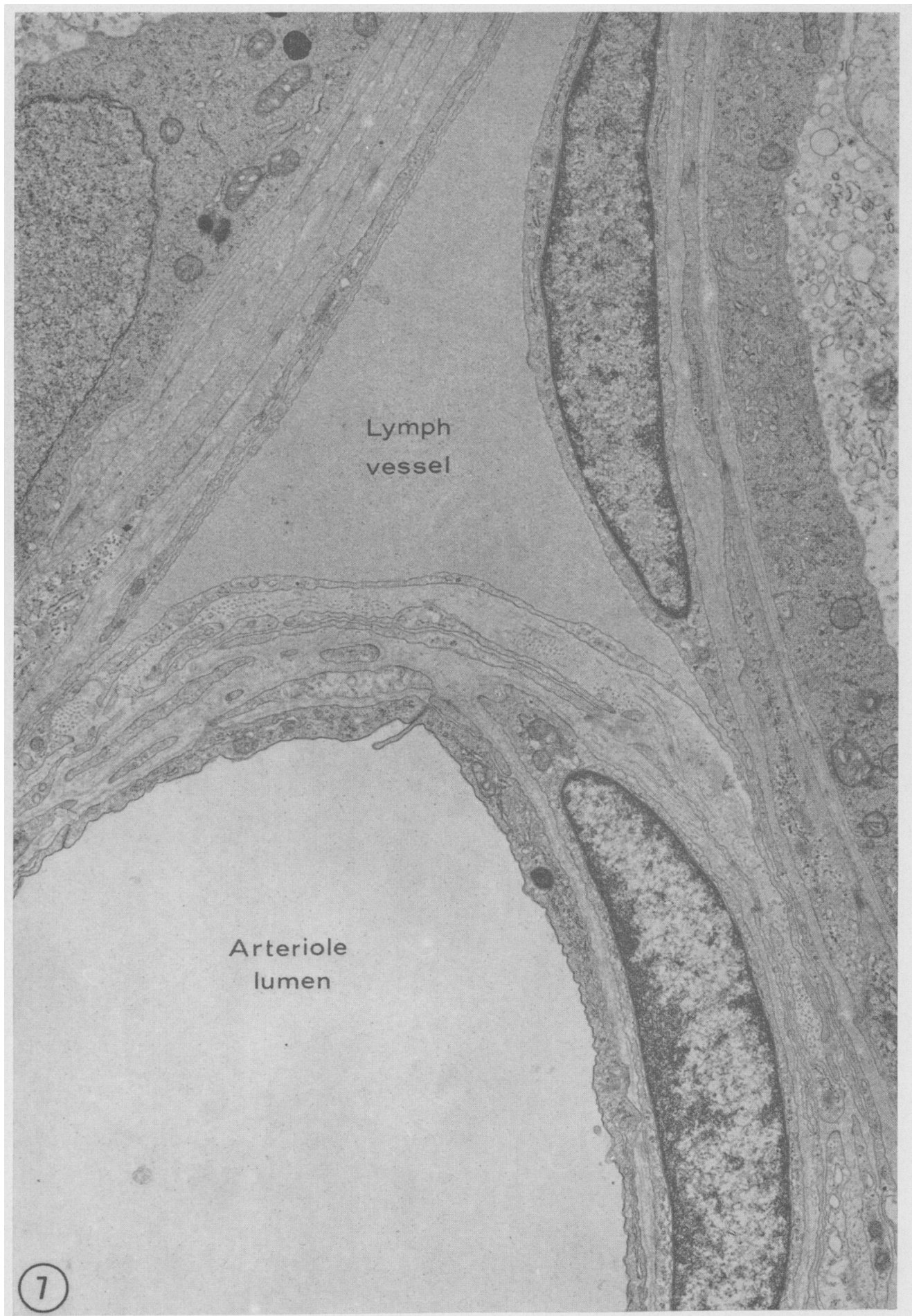


Testut, L. (1902) Traité d'anatomie humaine. Octave Doin, Paris.

Venable, J. H. \& Coggeshall, R. E. (1965) A simplified lead citrate stain for use in electron microscopy. 7. Cell Biol. 25, 407.

Vilar, O., Pérez del Cerro, M. E. \& Mancini, R. E. (1962) The Sertoli cell as a "bridge cell" between the basal membrane and the germinal cells. Expl Cell Res. 27, 158.

Voglmayr, J. K., Wartes, G. M. H. \& Setchell, B. P. (1966) Studies on spermatozoa and fluid collected directly from the testis of the conscious ram. Nature, Lond. 210, 861.

Von BRzezinski, D. K. (1963) Neue Befunde mit einer verbesserten Darstellung experimentell aufgefüllter Lymphkapillaren an Niere, Hoden-Nebenhoden, Dünn-und Dickdarm. Anat. Anz. 113, 289.

\section{EXPLANATION OF PLATES}

\section{PLATE}

Frg. 1. Photomicrograph of guinea-pig testis fixed by perfusion. Cytological details in the seminiferous epithelium are well preserved and the tubules are in close apposition with one another. There is no evidence of interstitial oedema. The blood vessels in the angular interstices between tubules are open and devoid of contents. The intertubular spaces on the other hand are filled by a homogeneous grey material of low density, $\times 270$.

FIG. 2. Photomicrograph of a somewhat larger interstitial space containing blood vessels of various sizes. The Leydig cells are associated with the walls of blood vessels but these are often larger than capillaries and have relatively thick walls. Gapillaries and venules such as the one at the right of the figure often have no associated Leydig cells. Between the base of the epithelium and the myoid layer of the tunica propria of the seminiferous tubule is a narrow clear zone of distinctly lower density than the contents of the intertubular space. The thin lines (at the arrows) traversing the interstitium and surrounding groups of vessels and Leydig cells are interpreted as sections of the endothelium of lymphatic sinusoids. $\times 270$.

\section{PLATE 2}

Fig. 3. Electron micrograph of the interspace between two seminiferous tubules filled by a thin-walled lymphatic containing a homogeneous precipitate of protein-rich lymph. At the upper right are shown the three principal layers of the tunica propria; the basal lamina of the seminiferous epithelium, the intermediate zone of sparse collagen fibrils, and the outer layer of myoid cells. External to this is the endothelium of the lymphatic vessel. It is noteworthy that the intermediate layer of the tunica propria contains no precipitate of protein such as is found throughout the interstitium. $\times 6200$.

\section{PLATE 3}

Fig. 4. Electron micrograph of interstitial tissue of the guinea-pig, showing a capillary above and the wall of a vein below. Leydig cells are associated with the vein but, in this instance, not with the capillary. The endothelium of a lymphatic vessel forms on one side a thin, limiting layer around the capillary and loose perivascular connective tissue, and on the other side is closely applied to the Leydig cells and adventitia of the vein. $\times 3500$

\section{PLATE 4}

Fig. 5. Electron micrograph of the periphery of a guinea-pig seminiferous tubule and the adjacent interstitial tissue. A sinusoidal lymphatic vessel is interposed between the tunica propria of the seminiferous tubule (at the left) and a cluster of Leydig cells associated with the wall of a vein (at the right). At the top of the figure, the arrow draws attention to a discontinuity in the endothelium through which the protein-rich fluid of the extravascular connective tissue is in continuity with the lymph in the lumen of the lymphatic. $\times 5200$

\section{PLATE 5}

Fig. 6. Electron micrograph of guinea-pig testis showing Leydig cells interposed between an arteriole and a lymphatic. The thin lymphatic endothelium follows the contours of the Leydig cell with a minimum of intervening connective tissue. This relationship would seem to facilitate entry of androgens into the lymph. $\times 11,200$.

\section{PLATE 6}

Fic. 7. Electron micrograph of intertubular tissue from chinchilla testis showing an arteriole (below) and an endothelial lined lymph vessel (above) occupying the triangular space between the blood vessel and the adjacent seminiferous tubules. The clear zone of the tunica propria which is prominent in the guinea-pig is poorly defined in the chinchilla. $\times 11,200$. 